Revista Brasileira de Higiene e Sanidade Animal Brazilian Journal of Hygiene and Animal Sanity

\title{
Dermatological manifestations associated with canine hypothyroidism: A review
}

\author{
Glícia Meneses Costa ${ }^{1}$, Steffi Lima Araujo² ${ }^{2}$ Francisco Antônio Félix Xavier \\ Júnior ${ }^{3}$, Daniel de Araújo Viana ${ }^{4}$, Janaina Serra Azul Monteiro Evangelista ${ }^{5}$. \\ 1. Programa de Pós-graduação em Ciências Veterinárias, Universidade Estadual do \\ Ceará, UECE - Médica Veterinária. E-mail: gliciamcosta@hotmail.com \\ 2. Faculdade de Veterinária, Universidade Estadual do Ceará, UECE - Graduanda. E- \\ mail: steffi.araujo@hotmail.com \\ 3. Faculdade de Veterinária, Universidade Estadual do Ceará, UECE - Médico \\ Veterinário. E-mail: juniorberith@gmail.com \\ 4. Faculdade de Veterinária, Universidade Estadual do Ceará, UECE - Médico \\ Veterinário. E-mail: viana_daniel@yahoo.com.br \\ 5. Laboratório de Morfologia Experimental Comparada do Programa de Pós-graduação \\ em Ciências Veterinárias, Universidade Estadual do Ceará, UECE - Médica \\ Veterinária. E-mail: janainaserrazul@gmail.com
}

\begin{abstract}
Canine endocrine dermatopathies account for $8.6 \%$ of the dermatological appointments, frequently presenting classic signs of non- pruritic bilaterally symmetrical alopecia that develops chronically. The most common are hypothyroidism, hyperadrenocorticism (HAC) and hyperestrogenism. Hypothyroidism is the most observed endocrine disease in dogs and it is characterized by a structural and / or functional abnormality in the gland, which leads to a deficient production of thyroid hormones. Clinical signs caused by insufficient thyroid hormones are commonly observed in the skin. Hormones produced by the thyroid are important in maintaining cutaneous function, once they perform a regulatory role in epidermal differentiation. Diagnosis of canine hypothyroidism is based on clinical and historical findings that are suggestive of the disease associated with supporting laboratory findings. The most frequently measured thyroid hormones are total tiroxine (TT4), total triiodothyronine (TT3) and free T4 (fT4). Skin biopsy may reveal histopathological findings highly suggestive of hypothyroidism such as vacuolization and arrector pili muscle hypertrophy. The combination of those knowledge is essential to the veterinarian when confronted with a chronic case of dermatological disorders, he or she may think about hypothyroidism as a possible diagnosis.
\end{abstract}

Keywords: Small animal nutrition, Feline, Neonate.

Autor para correspondência. E. Mail * E-mail: juniorberith@gmail.com

Recebido em 12.6.2016. Aceito em 28.12.2016

http://dx.doi.org/10.5935/1981-2965.20160064 


\section{Introduction}

Dermatology and Endocrinology are veterinary specialties on the rise today. In veterinary care provided in hospitals and clinics, $20-75 \%$ of cases are related to skin problems, $8.6 \%$ of these are caused by endocrinopathies. (SCOTT \& PARADIS, 1990; SCOTT et al., 2001; TEXEIRA et al., 2009; CARDOSO et al., 2011).

In Brazil, Machado et al. (2004) observed that the prevalence of dermatopathies was distributed by group of diseases: $44.4 \%$ of immunopathic origin; $20 \%$ parasitic; $12.4 \%$ seborrhoeanon-keratinisation complex; $11.2 \%$ bacterial; $6.4 \%$ fungal; $2.8 \%$ several; $2.0 \%$ endocrine and $0.4 \%$ congenital and hereditary. Souza et al. (2009) found a slightly higher percentage that $2.6 \%$ for endocrine diseases. Although, it was not observed by Gonçalves et al. (2009) in a survey acomplished in Brazil's midwest region, revealing a value of $0.5 \%$.

In the period between August 1998 and December 2005, 4107 dogs were care at the Animalia Veterinary Clinic, those $809(19.7 \%)$ were forwarded to the Dermatology department, of which 266 (32.9\%) had dermatopathies associated with hypothyroidism. It corresponds to $6.5 \%$ of the total number of care (TEXEIRA, 2008).
Skin reacts to injuries in many ways that can be expressed in determined diseases. Only one type of injury will hardly be specific to one disease. Juction of all information from skin disorders should be processed to determine tissue changes standards (HILL, 2005).

Among the tissue injuries in dogs, alopecia assumes great relevance, when it is especially associaed with endocrine diseases (FRANK, 2006). The types of alopecia present in dogs are: induced traumatic alopecia, parasitic alopecia, infectious and non-inflammatory alopecia. Alopecia may or may not show itching. (PARADIS \& CERUNDOLO, 2003).

Non-inflammatory alopecia is a current problem in dogs. However, the pathogenesis of that group of diseases are still uncertain. The diagnosis is based on history, clinical and laboratory findings and histopathology of skin biopsy. Probable diagnoses include hyperadrenocorticism, hypothyroidism, hyperestrogenism, alopecia $\mathrm{X}$ and recurrent flank alopecia (MÜNTENER, 2012).

When Scott et al. (2001) studied endocrinopathies with dermatologic disorders, he observed that changes caused by increase or decrease of certain hormones can cause alterations in 
folliculogenesis, pigmentation process and epidermopoiesis. Classical cutaneous manifestations of endocrine disorders are bilaterally symmetrical alopecia, hyperpigmentation, slow or absent repilation, and non-pruritc lesions (ARIAS \& JERICÓ, 1997, PORTO et al., 2008, MÜNTENER, 2012).

Through endocrine dermatopathies that belongs to non-inflammatory alopecia group, the most found, in descenting order, are hypothyroidism, hyperadrenocorticism,

hyperestrogenism and pituitary dwarfism. (SOUZA et al., 2009).

Hypothyroidism is the most common endocrinopathy of dogs. It has congenital or acquired origin and can be primary or secondary. The Primary form caracterizes for insufficient production of thyroid hormone. The secondary form is caused by an inadequate TSH production from the pituitary. (CASTILLO, 2011; SCARAMPELLA, 2011).

Deficient production of sexual and thyroid hormones modifies all of skin structures, independent of region or anatomical characteristics. Also, there is a increase of skin changes as effect of the hypothyroidism-castration association (FERREIRA et al., 2003).

Clinical manifestations caused by an imbalance of thyroid hormones are often observed in the skin where those hormones play a role of supporting as essential function. Thyroid hormone directly influence the mechanism of proteoglycan synthesis in the skin by stimulation of fibroblasts. In addition, they play a role in epidermal differentiation by their effect on keratinocytes, also it is essential in hair formation and sebum production (Doshi et al., 2008).

In a study conducted by a group of researchers from Rio de Janeiro, skin biopsy associated with histopathology were the most efficient diagnosis methods of hypothyroidism with specificity $100 \%$ and sensitivity $98.2 \%$. The specific alterations were hypertrophy with vacuolization of the arrector pili muscle and myxedema. It was observed that these alterations were found in $97.6 \%$ of the animals that have had the diagnosis of endocrinopathy confirmed by histopathology. Due to high specificity (100\%) and sensitivity (98.2\%), histopathology was the most effective diagnostic method for hypothyroidism, in this study (TEXEIRA, 2008).

Scott (1982) has observed that different endocrine disorders can occur with many histopathological findings. The most frequent are hyperkeratosis, follicular keratosis, follicular dilation, 
atrophy of the hair follicle, epidermal melanosis and atrophy of the sebaceous glands. These histological findings are indicative of endocrine disorders, but are not specific to any of them.

The definitive diagnosis of alopecia should be obtained through analysis with laboratory tests (microscopic examination of the skin, skin biopsies, blood and urine tests and hormonal tests) and clinical findings. The treatment of the patient affected by endocrine alopecia will depend on the diagnosed pathology (BOND, 2004).

Thus, the aim of this review was to describe a dermatatological aprroach about hypothyroidism, since the veterinarian came across patient which the main complaint of the owner is the skin lesion, usually cronic, without reporting behavioral or systemic alteration, faciliting this way the illness diagnosis.

\section{Hypothyroidism}

Hypothyroidism is a common cause of alopecia in human and domestic animals, especially in dogs (Doshi and Blumum, 2008; TSUJIO et al., 2008; ARTANTAS, 2009). Skin changes do not occur in isolation. Thyroid hormones stimulate different organs of the body by regulating the activity of enzymes and proteins that participate on cell metabolism, causing a wide variety of systemic clinical signs.

Hypothyroidism is the most frequently observed endocrine disease in dogs and it has as characteristic a structural and / or functional abnormality in the gland, which leads to deficient production of thyroid hormones (ETTINGER \& FELDMAN, 2010). In the human hair

follicle, the thyroid hormone receptor (TR) participates in the development of hair (SCARAMPELLA, 2011; MORAN \& CHATTERJEE, 2015). However, few researches have been studying the TRs and the pathological mechanism or pathway responsible for the alopecia caused by hypothyroidism (TSUJIO et al., 2008).

The main function of the thyroid is to control the body's metabolism through the secretion of its hormones: thyroxine (T4) and triiodothyronine (T3). Both are iodinated derivatives of the amino acid tyrosine and responsible for the biological effect of the gland. It is important to note that, beyond the follicular cells producing the hormones, the thyroid has parafollicular cells, producing calcitonin (CUNNINGHAM, 2004).

According to the literature, breeds more predisponents to suffer that 
disorder are: tGolden Retriever, Doberman Pinscher, Irish Setter, Miniature Schnauzer, Dachshund, Cocker Spaniel, Airdale Terrier, Boxer, Poodle, Borzoi, Beagle, Irish Setter and Old English Sheepdog (SCOTTMONCRIEFF, 2007). However, in a study conducted by Teixeira (2008), dogs with no defined racial pattern were the most affected by hypothyroidism.

The age which the first clinical signs begin to appear is quite variable. Clinical manifestations of hypothyroidism emerge earlier in predisposed breeds (NELSON \& COUTO, 2009). The origin of this disease may be congenital or acquired. Acquired hypothyroidism can be primary or secondary. The primary hypothyroidism, it is caused by insufficient production of thyroid hormones by the thyroid gland, whereas the secondary form is caused by glandular dysfunction due to the insufficient TSH production from pituitary (ETTINGER \& FELDMAN, 2010; SCARAMPELLA, 2001).

Due to the diversified symptoms and the association with variable or doubting laboratory results caused by physiological fluctuation of thyroid hormone values, it is difficult to achive at the definitive diagnosis of hypothyroidism. Despite these facts, it is the most diagnosed endocrine disorder in dogs (SCOTT et al, 2001; SCOTTMONCRIEFF, 2007).

Sexual predisposition is still a questionable factor among authors. In a study conducted by Teixeira (2008), of the 266 dogs with hypothyroidism, 154 were female $(57.9 \%)$, of which 44 were neutered and 110 were unneutered, and 112 were male (42.1\%), 32 neutered and 80 unneutered; Showing no significant differences related to sex.

\section{Hypothalamic - pituitary - thyroid axis}

The regulation of the hypothalamic-pituitary axis of the thyroid depends on daily synthesis and secretion of T4. The production of thyroid hormones is directly controlled by TSH, which is produced and secreted by the thyrotrophic cells of the adenohypophysis. The release of TSH is regulated by TRH production, which is produced in specific neurons in the paraventricular nucleus of the hypothalamus (CUNNINGHAM, 2004).

T4 plays a role of inhibiting TRH synthesis by the hypothalamus and respectively TSH in the pituitary. If there is a reduction in $\mathrm{T} 4$ synthesis, neither the hypothalamus or thyrotrophic cells are inhibited and both TRH and TSH increase. In contrast, increasing $\mathrm{T} 4$ synthesis, a higher conversion of $\mathrm{T} 4$ to T3 occurs, with TRH and TSH 
inhibition. Plasma levels of thyroid hormones are constantly maintained through a negative feedback mechanism, it involves the pituitary and hypothalamus. Free thyroid hormones ensure the proper functioning of this mechanism. Glucocorticoids and androgens also inhibit TSH secretion (Dixon, 2001; Cunningham, 2004).

\section{Classification of Hypothyroidism}

Canine hypothyroidism is classified as primary, secondary or tertiary, also can be classified by natural or iatrogenic occurrence (FERGUNSON, 2007; SCOTTMONCRIEFF, 2007; ETTINGER \& FELDMAN, 2010). The origin of this endocrinopathy is still highly discussed, and its cause may have an acquired or genetic origin.

Major forms of primary hypothyroidism are autoimmune lymphocytic thyroiditis and idiopathic thyroid atrophy, both of them are very common, about $50 \%$ of the cases of the disease are caused by lymphocytic thyroiditis (KEMPPAINEN \& CLARK, 1994; ETTINGER \& FELDMAN, 2010).

The main histological characteristic of lymphocytic thyroiditis is the presence of a lymphocytic infiltrate and macrophages that destroy the follicular region interfering in hormone production by the thyroid gland (SCOTT et al., 2001; ETTINGER \& FELDMAN, 2010).

The etiology of idiopathic thyroid atrophy has been discussed yet. In idiopathic atrophy, there is parenchymal loss and replacement for adipose tissue and connective tissue fibers. Individual degeneration of follicular cells occurs with exfoliation of cells inside the colloid (ETTINGER \& FELDMAN, 2010).

The presence of inflammatory infiltrate is not observed, even in areas where small follicles or follicular remains are present (NELSON \& COUTO, 2009).

Other authors indicate that the possible presence of inflammatory infiltrate would characterize it as a final stage of lymphocytic thyroiditis (SCOTT et al, 2001).

Secondary hypothyroidism is rare, it occurs in a smaller small portion of the cases $(10 \%)$. Pituitary disorders, such as hyperplasia or neoplasia, cause reduction of thyroid functions (Scott et al., 2001; ETTINGER \& FELDMAN, 2010).

Changes associated with the hypothalamus are classified as central form, but have not been described in dogs yet, that would be described as tertiary hypothyroidism

(NELSON \& COUTO, 
2009; ETTINGER \& FELDMAN, 2010).

Congenital hypothyroidism is rarely diagnosed in dogs, its possible causes are iodine deficiency, deficiencies in the enzyme tiroperoxidase or defects in the development of the thyroid gland. Defect in the secretion of TSH is a less common cause such as deficient TSH receptor or anomalous TSH (SCOTT et al, 2001; CASTILLO et al., 2001; NELSON \& COUTO, 2009).

Iatrogenic hypothyroidism can be caused by administration of antithyroid drugs, iodine treatment, thyroidectomy (SCOTT-MONCRIEFF, 2007 , ETTINGER \& FELDMAN, 2010).

Diet with excess iodine has been associated with morphological and functional changes in the thyroid, so thyroid hormone procuction is affected (CASTILLO et al, 2001). The excess of iodine present in commercial diets may induce thyroid disorder and consequent hypothyroidism (CASTILLO et al, 2001b).

\section{Clinical Sings}

Thyroid hormones influence the function of many organs, so the systemic clinical signs of hypothyroidism are nonspecific and o very variable, rarely assuming specific aspects. The most common signs of endocrinopathy are those related to decreased metabolism and dermatological changes. Less common but they have been documented: neurological manifestations, effects on the cardiovascular system and the female reproductive system. Some clinical changes that have been attributed to hypothyroidism, there are strong evidences of their association, include behavioral changes, male infertility, ophthalmological disorders, coagulopathies and gastrointestinal dysfunctions (SCOTT-MONCRIEFF, 2007; ETTINGER \& FELDMAN, 2010).

Many dogs are prone to gain weight, even without increasing their food intake. Most dogs affected by hypothyroidism have some degree of mental retardation, lethargy, intolerance, or exercise aversion. The appearance of these signs occurs gradually and insidiously, often they are not recognized by the owner. (NELSON \& COUTO, 2009; SCOTT-MONCRIEFF, 2007).

The central and peripheral nervous system can be affected by hypothyroidism. In a retrospective study of 66 dogs with hypothyroidism, neurological abnormalities were described in $29 \%$ of dogs, although all neurological signs described can not be attributed to hypothyroidism 
(PANCIERA, 1994). The most common neurological manifestations of hypothyroidism are related to the peripheral nervous system, dysfunctions correlated to the central nervous system are also reported. The causes of neurological dysfunction in hypothyroidism are poorly understood. ATP deficiency leads to an imbalance in $\mathrm{Na}^{+} / \mathrm{K}^{+}$pump activity, which may cause a delay in axonal transport and synapse of the nerve, causing peripheral nerve dysfunction (SCOTT-MONCRIEFF, 2007).

Peripheral neuropathy is a better documented neurological manifestation in hypothyroidism. Dogs affected show exercise intolerance, muscle weakness, ataxia, especially of the pelvic limbs, tetraplegia or paralysis, proprioceptive deficits and decreased spinal reflexes (ETTINGER \& FELDMAN, 2010).

Other signs may be associated with hypothyroidism, although their are not completely proved, and also in these normally do not observe apparent resolutions with levothyroxine supplementation. They are Horner's syndrome, facial paralysis, bilateral laryngeal paralysis and megaesophagus (NELSON \& COUTO, 2009).

Ophthalmic manifestations related to hypothyroidism are corneal lipidosis, corneal ulcer, uveitis, secondary glaucoma, dry keratoconjunctivitis. However, these signs have not been proven yet (FRANK, 2006; ETTINGER \& FELDMAN, 2010).

Deficiency of thyroid hormones has the potential to affect cardiac function. Thyroid hormones have a positive ionotropic effect on the myocardium, also stimulate myocardial hypertrophy and increase heart responsiveness to adrenergic stimulation. (Dixon, 2004). Bradycardia is a frequent clinical sign (SCARAMPELLA, 2011). Reported electrocardiographic abnormalities include fibrillation (SCOTTMONCRIEFF, 2007).

Reproductive changes attributed to hypothyroidism in females include gynecomastia and galactorrhea in $25 \%$ of unneutered bitches (SCOTT et al., 2001; SCARAMPELLA, 2011). The probable cause of these symptoms is due to the presumed increase in the general stimulation of the pituitary by HRT (DIXON, 2004). Other observed manifestations are silent estrus, prolonged estrus interval, estrous cycle failure, reduced number of pups in the litter, miscarriage, weak or stillborn pups, and uterine inertia (ETTINGER \& FELDMAN, 2010). The reproductive changes most frequently found in males are loss of libido (CASTILLO, 2011), 
infertility and testicular atrophy (FRANK, 2006).

\section{Dermatological Changes}

Thyroid hormones are extremely important in maintaining cutaneous function, they play a regulatory role in epidermal differentiation, in part because of their effects on keratinocytes (DOSHI, BLYUMIN \& KIMBALL, 2008). Thus, dermatological symptoms are important alterations in animals with hypothyroidism. Some signs may be common to other endocrine or nonendocrine diseases.

The major alterations are noninflammatory non- pruritic bilaterally symmetrical alopecia, and tragic face associated with other cutaneous manifestations (SCOTT et al, 2001; NELSON \& COUTO, 2009; MÜNTENER et al., 2012).

Dermatological signs appear later, when T4 secretion is severely affected. $20 \%$ of the dogs with hypothyroidism will not present generalized alopecia, however it is common to observe presence of dry or oily seborrhea (CASTILlO, 2011).

Most the hair follicles of thyroidectomized rats showed the presence of the telogenic phase and a follicular atrophy involving thickness decreasing of outer root sheath and inner root sheath of the hair follicle (TSUJIO et al., 2008). Reducting thyroid hormones maintains the hair follicles in telogenic phase and inhibits anagen phase, which leads to signs of frosted, dry and brittle hair (SCOTT et al, 2001; MÜNTENER et al., 2012). Hair loss is usually the first symptom perceived by owners, it occurs bilaterally and symmetrically in dorsal region of the neck, ventral and lateral of the thorax, abdomen and tail. Head and extremities are usually spared (SCOTTMONCRIEFF, 2007). Very commom caracterist is the "rat's tail" which it is alopecia located in the tail (SCOTT et al, 2001).

Hyperpigmentation is often observed in dogs with hypothyroidism, but its mechanism is still unknown (SCOTT-MONCRIEFF, 2007; SCARAMPELLA, 2011). Hyperpigmentation usually begins in areas with alopecia. This alteration, also affects inguinal region and medial faces of the limbs. In dogs with endocrine dermatopathy, hyperpigmented areas may also present hyperkeratosis when they are related to pruritus and chronic inflammation of the skin (SCOTT et al, 2001; SCOTT-MONCRIEFF, 2007).

\section{Hyperkeratosis,}

hyperpigmentation, comedo formation, and low healing are frequently observed in dogs with hypothyroidism that also 
develop oily seborrhea. Comedones are lesions that are also present in hyperadrenocorticism, as well as demodicosis and follicular dysplasia (SCOTT et al, 2001; SCOTTMONCRIEFF, 2007).

A very commom skin alteration of hypothyroidism is dry seborrhea. It arises in lack of thyroid hormones, since the absence of those hormones leads to a lack of control of the secretion of the sebaceous gland and deficiency in cell maturation, in superficial layers of the epidermis. However, oily seborrhea occurs due to accumulation of secretion in the sebaceous gland, which can not excrete it (SCOTT et al, 2001; NELSON \& COUTO, 2009). Ceruminous ear glands and sebaceous glands have the same histological origin and both glands are influenced by hypothyroidism and they are soperestimulated causing ceruminous otitis. Excess secretion predisposes to the development of secondary infections (bacterial and / or fungal) (SCOTT et al, 2001).

Thyroid hormones stimulate fibroblasts proliferation and collagen synthesis. Also, they influence the thickness of the skin by regulating synthesis and catabolism of glycosaminoglycans. If those hormones are private, there is a decrease of catabolism and hyaluronic acid accumulates in the dermis, leading to water retention. The resulting is myxedema that gives to skin a thicker and lower temperature (SCARAMPELLA, 2011). Myxedema is usually observed on dog's face, around the temporal frontal region. Swelling and thickening of facial skinfolds, and drooping upper eyelids, generating the famous tragic facial expression (SCOTT-MONCRIEFF, 2007).

Canine hypothyroidism predisposes to recurrent bacterial infections in the skin, being pyoderma reported in $10-23 \%$ of cases. Infections for Malassezia sp. and demodicosis were also reported (SCOTT-MONCRIEFF, 2007). Hyperkeratosis is usually a common histopathological finding in chronic cases, its occurrence is due to deficiency of prostaglandin E2, which is responsible for the control of keratinization (NELSON \& COUTO, 2009; SCOTT et al, 2001).

\section{Diagnosis}

Diagnosis of canine hypothyroidism is based on clinical and historical findings that are suggestive of the disease associated with supporting laboratory findings and responsive hormonal therapy (CASTILLO, 2011).

It is often difficult to confirm this disease; The final diagnosis is sometimes based on the positive response to $\mathrm{T} 4$ 
replacement therapy. Therefore, confirmation of hypothyroidism remains difficult in a significant percentage of dogs. The most common situations are those involving dogs with clinical signs suggestive of hypothyroidism, however they have hormonal test results within the lower limit or dogs with the test results for hypothyroidism but are ill and / or given medications that may interfere in the results. So, it is recommended reevalute thyroid status after disease solved or after discontinuing medication. however, this is not possible in all cases. This is sometimes recommended for therapeutic T4 synthetic screening (KEMPPAINEN \& BEHREND, 2001).

Analytical changes include nonregenerative, normocytic and normocromic anemia (DIXON, 2001; FRANK, 2006). The most consistent biochemical changes found are hyperlipidemia, usually attributed to hypercholesterolemia and, less frequently, hypertriglyceridemia (FRANK, 2006; CASTILLO, 2011). Moderate increase in ALT and FA liver enzymes is observed in some cases (CASTILLO, 2011).

Cutaneous biopsy may reveal histopathological findings suggestive of hypothyroidism, such as vacuolization and hypertrophy of arrector pili muscle that occur in $74 \%$ of the dogs affected by this pathology. Increasing production of dermal mucin (myxedema), and thickening of the dermis are characteristic observed in these animals (TEIXEIRA, 2008). Also, Low percentage of hair follicles in the anagen phase, besides the existence of thickening of the dermis and epidermis (MÜNTENER et al., 2012). Nearly 50\% of the skin biopsies of dogs with hypothyroidism showed a varying degree of inflammation, because of frequent incidence of secondary seborrhea, pyoderma bacterial or both (Scott et al., 2001).

In the study conducted by Teixeira (2008), 266 animals were diagnosed with hypothyroidism and histopathology was used as a diagnostic method for the disease in $218(81,9 \%)$. In 214 (98.2\%) animals, changes suggestive of hypothyroidism were observed, whereas in only four dogs $(1.8 \%)$ there were no signs of this endocrinopathy by microscopic examination of the skin structures. For that study, skin biopsy and histopathology was the most effective method in the diagnosis of hypothyroidism with specificity of $100 \%$ and sensitivity of $98.2 \%$.

In a study in Japan, skin biopsy revealed throught immunohistochemistry that there is a decrease in thyroid hormone receptor 
(TR) expression and cell proliferative activity of hair follicles in thyroidectomized rats, in other words, lacking thyroid hormones result in delayed hair growth. (TSUJIO et al., 2008).

The most frequently measured thyroid hormones are total T4 (TT4), total T3 (TT3) and free T4 (fT4). Free T3 (fT3) and reverted T3 (rT3) concentration are less used (KEMPPAINEN \& BEHREND, 2001; ETTINGER and FELDMAN, 2010).

Basal serum concentration of $\mathrm{T} 4$ is the sum of free T4 concentration and T4 bound to proteins circulating in the blood. Serum T4 measurement can be used as a screening test for the diagnosis of hypothyroidism (NELSON \& COUTO, 2009). Single dose of TT4 concentration in the serum by radio immunoassay is only diagnosed, if the value is within normal or elevated. This becomes very significant because hypothyroidism can be excluded if normal values are found. However, a low level of $\mathrm{T} 4$ is not sufficient for the confirmation of hypothyroidism (DIXON, 2001). In most cases, dogs with hypothyroidism may be distinguished from normal dogs based on low plasma TT4 concentration earlier in the morning, but several non-thyroid diseases and administrationn of different drugs including glucocorticoids, sulphonamides, anticonvulsants, nonsteroidal anti-inflammatory drugs (NSAIDs) and radiocontrast agents may "fake" the decrease of serum T4 concentrations (Dixon, 2001; Kemppaine \& Behrren, 2001; Ferguson, 2007).

FT4 is the circulating thyroxine fraction that did not conjugate to plasma proteins (usually $0.1 \%$ of TT4). The measurement of fT4 provides an analysis of the hormone concentration available for the tissues. It has been shown that there is a high correlation between the clinical status of the animal and the amount of free T4 (DIXON, 2001; FERGUSON, 2007).

$\mathrm{T} 3$ is the most potent thyroid hormone at the cellular level. However, in dogs, a large proportion (40-60\%) is not produced by thyroid gland and it is not the predominant hormone in the circulation. T3 is mostly formed through T4 deiodination outside the tiroid gland (FERGUNSON, 2007). Measurement of TT3 in the evaluation of dogs with hypothyroidism is not recommended (KEMPPAINEN \& BEHREND, 2001). Basal TSH levels is usually increased in dogs with hypothyroidism (DIXON, 2001). TSH is considered the best tool for evaluation of the hypothalamicpituitary axis of the thyroid, besides it is 
the most sensitive marker to determine the functionality of this gland. Increasing in TSH can be considered for the diagnosis of hypothyroidism, independent of T4 values (CASTILLO, 2011).

Currently, stimulation test with $\mathrm{TSH}$ is the most reliable diagnostic method for thyroid function in dogs (DIXON, 2001). The principle of this test is to evaluate TT4 concentration after administration of TSH. It is considered the gold test for the evaluation of thyroid gland function (KEMPPAINEN \& BEHREND, 2001; FERGUNSON, 2007). According to Kemppainen and Behrend (2001), the use of the TSH stimulation test is unsatisfactory. TSH administration results in low or inconsistent TT4 plasma increase in euthyroid dogs.

TRH stimulation test for $\mathrm{T} 4$ or TSH measurement was proposed, however, this assay is not strongly sensitive for the diagnosis of hypothyroidism. Theoretically, dogs with hypothyroidism did not show a response to TRH administration (FERGUNSON, 2007).

The existence of autoantibodies is based on the idea that hypothyroidism in most dogs, appears to be related to an autoimmune thyroid attack. The most commonly used autoantibody is the anti- thyroglobulin antibodies (ATgA), however, they are not observed in cases of idiopathic atrophy but they have already been observed in some euthyroid dogs. The levels of ATgAs as a diagnosis of hypothyroidism need to be interpreted with great caution, since a negative result may not rule out hypothyroidism (DIXON, 2001). Anti-T4 and thyroid anti-T3 antibodies are much less common in dogs with hypothyroidism. The prognostic significance of the presence of autoantibodies to thyroglobulins, T4 and T3 is uncertain. In a study conducted by Kemppainen and Behrend (2001) there was not recommendation for routine titration of these autoantibodies, since their occurrence was low. Fergunson (2007) has observed that the presence of ATgA appears as an initial indicator of pathological changes in the thyroid.

Thyroid biopsy is a definitive test to identify lesions such as lymphocytic thyroiditis, but the presence of lesion in the thyroid gland does not necessarily mean that there is a functional abnormality. This test is quite unusual in the diagnosis of thyroid dysfunction in dogs (ETTINGER \& FELDMAN, 2010).

There are several differential diagnoses for hypothyroidism, including canine hyperadrenocorticism (HAC), 
dermatoses responsive to changes in sex hormones, alopecia $\mathrm{X}$, color mutant alopecia, cyclical flank alopecia, congenital alopecia, telogen effluvium / anagenic flux, pattern alopecia, dermatophytosis, demodicosis and superficial pyoderma (SCARAMPELLA, 2011; MÜNTENER et al., 2012).

\section{Treatment}

Treatment of hypothyroidism aims to normalize the thyroid axis and circulating T4 levels (CASTILLO, 2011). In primary hypothyroidism treatment is continuous, so the patient will be treated throughout his life (Scott et al., 2001).

The treatment with synthetic levothyroxine is recommended, in order to restore euthyroid status without suppressing the axis (NELSON \& COUTO, 2009; CASTILLO, 2011). The recommended dose of levothyroxine is $11-22 \mu \mathrm{g} / \mathrm{kg}$, administered once or twice daily. Ideally, starting with the lowest dose and then increasing the dosage gradually until intended concentration to be reached (CASTILLO,

2011;

TVARIJONAVICIUTE, 2013). When the medication is given along with food a decrease in bioavailability occurs. Treatment with levothyroxine preserves the normal regulation of $\mathrm{T} 4$ to $\mathrm{T} 3$ conversion, thus allowing the regulation of $\mathrm{T} 3$ concentrations in tissues, reducing the risk of iatrogenic hyperthyroidism (ETTINGER \& FELDMAN, 2010).
When there is inadequate absorption of $\mathrm{T} 4$, treatment with synthetic $\mathrm{T} 3$ is recommended as the gastrointestinal absorption of T3 is $100 \%$. However, this treatment is not the most recommended, because T3 has a short average life and it is necessary to administer it three times a day. In addition, it is the most common cause of iatrogenic hyperthyroidism (ETTINGER \& FELDMAN, 2010).

Treatment corrects most of the cutaneous and metabolic changes of hypothyroidism. Animals tend to lose the weight they gained before treatment started (TVARIJONAVICIUTE, 2013). Dogs with some behavioral changes, such as lethargy and depression, exhibit a rapid response to levothyroxine (2-4 weeks). The dermatological response occurs slower and this should be reported to the owner, showing the importance of maintaining the administration of the drug for at least three months. Improvement of the initial cutaneous manifestations generally takes about four weeks to be noticed. Most animals show complete or partial recovery of the skin at the end of three or four months; hair growth may take longer in larger breeds (Scott et al., 2001).

Treatment should be monitored every two months, with collection of blood samples 3-4 hours after the administration of levothyroxine. Depending on the results the dose should be adjusted. Subsequently, reevaluation can be performed 6-12 month, if the patiente had improved (CASTILLO, 2011). 


\section{Conclusion}

In this way, hypothyroidism should be considerated as a possible diagnosis when the veterinarian is confronted with a canine patient who has chronic and recurrent dermatological alterations and then, establishing the institution of the best treatment for the patient.

\section{References}

1.ARIAS, M.V.B. \& JERICÓ, M.M. Diabetes mellitus associada a dermatopatia em cão - relato de caso. Ciência Rural, Santa Maria, v.27, n.4, p.675 - 679, 1997.

2. ARTANTA Ş, Ş.; GÜL, Ü.; KILIÇ, A., GÜLER, S. Skin findings in thyroid diseases. European Journal of Internal Medicine, Prague, v. 20, p. 158 - 161, 2009.

3. BOND, R. Investigation of Symmetrical Alopecia in dogs. In: MOONEY, C.T. E PETERSON, M.E. BSAVA Manual of Canine and Feline Endocrinology. 3 ed. Gloucester, England: British Small Animal Veterinary Association, 2004. Cap.8, p.57 64.

4. CARDOSO, M.J.L.; MACHADO, L.H.A.; MELUSSI, M.; ZAMARIAN, T.P.; CARNIELLI, C.M.; JUNIOR, J.C.M.F. Dermatopatias em cães: revisão de 257 casos. Archives of Veterinary Science, Curitiba, v.16, n.2, p.66 - 74, 2011.

5. CASTILlO, V.A. Hipotiroidismo Canino. Veterinary Focus, Boulogne, V.21, n. 1, p. 2 - 8, 2011.

6. CASTILLO, V.A.; LALIA, J.C.; JUNCO, M.; SARTORIO, G; MÁRQUEZ, A.G.; RODRIGUEZ, M.S.; PISAREV, M.A. Changes in thyroid function in puppies fed a high iodine comercial diet. The Veterinary Journal, England, n.161, v. 1, p. 80-84, 2001.
7. CASTILLO, V.A.; PISAREV, M.A.; LALIA, J.C., RODRIGUÉZ, M.S.; CABRINI, H.L.; MÁRQUEZ, A.G. Commercial diet induce hypothyroidism due to high iodine. Histopathological and radiological analysis. Veterinary Quarterly, England, v.23, p.218-223, 2001(b).

8. CUNNINGHAM, J.G. Tratado de Fisiologia Veterinária. 5th ed. São Paulo: Elsevier, 2014. p.374 - 405.

9.DIXON, R. Recent developments in the diagnosis of canine hypothyroidism. In Pratice, United Kingdom, n.23,v.6, p..328 334, 2001.

10.DIXON, R.M. Canine Hypothyroidism. In: MOONEY, C.T \& PETERSON, M.E. BSAVA Manual of Canine and Feline Endocrinology. 3 ed. Gloucester, England: British Small Animal Veterinary Association, 2004, Cap.10, p.76 - 94.

11.DOSHI, D.N.; BLYUMIN, M.L.; KIMBALL, A.B. Cutaneous manifestations of thyroid disease. Clinics in Dermatology, Philadelphia, v.26, p.283-287, 2008.

12.ETTINGER, S.J.; FELDMAN, E.C. Hypothiroidism and Hyperadrenocorticism. Textbook of Veterinary Internal Medicine. 7 ed. Elsever Saunders. 2010.

13.FERGUSON, D.C. Testing for Hypothyroidism in Dogs. Veterinary Clinics Small Animal Practice, v.37, p.647-669, 2007.

14.FERREIRA, E.; SERAKIDES, R.; NUNES, V.A.; GOMES, M.G.; SILVA, C.M.; OCARINO, N.M.; RIBEIRO, A.F.C. Morfologia e histoquímica da pele de ratas hipotireóideas castradas e não castradas. Arquivo Brasileiro de Medicina Veterinária e Zootecnica, Belo Horizonte, v.55, n.1, 2003. 
15.FRANK， L.A.; DONNELL， R.L.; KANIA, S.A. Oestrogen Receptor Evaluation in Pomeranian Dogs with Hair Cycle Arrest (Alopecia X) on Melatonin Supplementation. Veterinary Dermatology, United Kingdom v.17, p.252 - 258, 2006.

16. GONÇALVES, V.D; RODRIGUES, L.F.; TEXEIRA, A.S.; MENDONÇA, M.L.; SILVA, A.C.R.; SEGATO, M.B.R. Prevalência das dermatopatias alérgicas em cães e gatos na cidade de Rio Verde - GO, BRASIL. In: V Jornada e IV Mostra Científica da Faculdade de Medicina Veterinária 24 e 25 de novembro de 2009.

17. HILL, P. Clinical Approach to Alopecia in Dogs - Will the Hair Grow Back? The Royal school Of Veterinary Studies. The University of Edinburgh, Scotland. Published in IVIS whit permission of the North American Veterinary Conference. p.263 - 268, 2005. Disponível em: http://www.ivis.org/proceedings/navc/2005/ SAE/100.pdf?LA=1. Acesso em : $01 \mathrm{de}$ dezembro de 2016.

18.KEMPPAINEN, R.J. \& BEHREND, E. N. Diagnois of canine hypothyrodism. Veterinary Clinics of North America Small Animal Practice, Maryland Heights, v. 31, n. 5, 2001.

19. KEMPPAINEN, R.J.; CLARK, T.P. Etiopathogenesis of canine hypothyroidism. Veterinary Clinics of North America Small Animal Practice, Maryland Heights, n. 24, v. 3, p. $467-476,1994$.

20. MACHADO, M.L.S.; APPELT, C.E. \& FERREIRO, L. Dermatófitos e leveduras isolados da pele de cães com dermatopatias diversas. Acta Scientiae Veterinariae, Porto Alegre, v.32, n.3, p.225-232, 2004.

21. MORAN, C. \& CHATTERJEE, K. Resistance to thyroid hormone due to defective thyroid receptor alpha. Best Practice \& Research Clinical Endocrinology \& Metabolism, Philadelphia, v.29, p.647 - 657, 2015.
22. MÜNTENER, T.; SCHUEPBACHREGULA, G.; FRANL, L.; RÜFENACHT, S. \& WELLE, M.M. Canine noninflammatory alopecia: a comprehensive evaluation of common and distinguishing histological characteristics. Dermatology Veterinary, United Kigdom, v. 23, $206-$ 244, 2012.

23. NELSON, R.W \& COUTO, C.G. Disorders of Thyroid Gland and Disorders of the Adrenal Gland. Small Animal Internal Medicine. 4th Ed. 2009.

24. PANCIERA, D.L. Hypothyroidism in dogs: 66 cases (1987-1992). Journal American Veterinary Medical Association, Schaumburg, v. 5, n. 204, p.761 - 767, 1994.

25. PARADIS, M \& CERUNDOLO, R. An Approach to Symmetrical Alopecia in the Dog. In: Foster, A; Foil, C. Eds. BSAVA Manual of Small Animal Dermatology. $2^{a}$ Ed. British Small Animal Veterinary Association. Barcelona, 2003, p.83 - 90.

26. PORTO, R.N.G.; MOURA, V.M.B.D.; SANTIN, A.P.I.; ALVES, C.E.F.; SALES, T.P.; MATOS, M.P.C.; MIGUEL, M.P.; BRITO, L.A.B. Tireoidite linfocítica canina em um Bull terrier. Acta Scientiae Veterinariae, Porto Alegre, v.36, n.3, p.285 - 288, 2008.

27. SCARAMPELLA, F. Alopécia Endócrina no Cão. Veterinary Focus, Boulogne, v. 21, n.1, p. 40 - 46, 2011.

28. SCOTT, D.W. Histopathologic findings in endocrine skin disorders of the dog. Journal of the American Animal Hospital Association, Lakewood, v. 18, p. 173 - 183, 1982.

29. SCOTT-MONCRIEFF, J.C. Clinical Signs and Concurrent Diseases of Hypothyroidism in Dogs and Cats. Veterinary Clinics Small Animal Practice, Maryland Heights, v.37, p.709 722, 2007. 
30. SCOTT, D.W.; MILLER, D.H.; GRIFFIN, C.E. Muller \& Kirk - Small animal dermatology. 6th.ed. Philadelphia: Sauders, 2001.

31. SCOTT, D.W. \& PARADIS, M.A survey of canine and feline skin disorders seen in a university practice: Small Animal Clinic, University of Montréal, SaintHyacinthe, Québec (1987-1988). Canadian Veterinary Journal, Otawa, v.31, n.12, p.830-835, 1990.

32. SOUZA, T.M.; FIGHERA, R.A.; SCHIMIDT, C.; RÉQUIA, A.H.; BRUM, J.S.; MARTINS, T.B.; BARROS, C.S.L. Prevalência das dermatopatias não tumorais em cães do município de Santa Maria, Rio Grande do Sul (2005-2008). Pesquisa Veterinária Brasileira, Seropédica v.29, n.2, p. 157 - 162, 2009.

33. TEXEIRA, A.S.; MENDOÇA, M.L.; GONÇALVES, V.D.; RODRIGUES, L.F.; SILVA, A.C.R; RIBEIRO, R.G. Estudo retrospectivo das dermatopatias mais prevalentes em cães e gatos na cidade de Rio Verde - GO, Brasil. In: V Jornada e IV Mostra Científica da Faculdade de Medicina Veterinária 24 e 25 de novembro de 2009.

34. TEXEIRA, R.D.S. Hipotireoidismo em cães dermatopatas: aspectos clínicolaboratoriais comparados ao exame histopatológico da pele. (Dissertação de Mestrado) - Universidade Federal Rural do Rio de Janeiro, RJ, 2008.

35. TSUJIO, M.; YOSHIOKA, K.; SATOH, M.; WATAHIKI, Y. \& MUTOH, K. Skin Morphology of Thyroidectomized Rats. Veterinary Pathology, United Kingdom, v. 45, p. $505-511,2008$.

36. TVARIJONAVICIUTE, A., JAILLARDON, L.; CERÓN, J.J.; SILIART, B. Effects of thyroxin therapy on different analytes related to obesity and inflammation in dogs with hypothyroidism. The Veterinary Journal, United Kingdom v. 196, p.71-75, 2013. 